Int. J. Electrochem. Sci., 15 (2020) 3127 - 3142

\title{
Biosensors for $\beta 17$-estradiol detection based on graphene quantum dots (GQDs)/conducting polymer and laccase modified platinum/gold electrodes
}

\author{
Kamila Spychalska, Sylwia Baluta, Agnieszka Świst, Joanna Cabaj ${ }^{*}$ \\ Faculty of Chemistry, Wroclaw University of Science and Technology, Wybrzeże Wyspiańskiego 27, \\ 50-370 Wroclaw, Poland \\ *E-mail: joanna.cabaj@pwr.edu.pl
}

doi: $10.20964 / 2020.04 .37$

Received: 14 October 2019 / Accepted: 24 December 2019 / Published: 10 March 2020

\begin{abstract}
A convenient electrochemical sensing pathway was investigated for $\beta 17$-estradiol determination based on graphene quantum dots (GQDs)/conducting polymer and laccase modified platinum (Pt)/gold (Au) electrodes. The miniature estradiol biosensors were created through the immobilization of laccase on the surface of an electroactive layer of an electrode coated with GQDs or with electroconducting polymer - poly(4-(5-hexylthiophen-2-yl)-2,6-bis(5-(selenophen-2-yl)thiophen-2-yl)pyridine). This sensing arrangement utilized the catalytic oxidation of $\beta 17$-estradiol to a reactive oxygen agent, and then to oligomeric structures. The process of hormone determination was based on the redox reaction using the presence of the laccase enzyme. Under optimized conditions, the constructed systems demonstrated a convenient degree of sensitivity $-0.25-0.75 \mu \mathrm{A} \mathrm{mM}^{-1} \mathrm{~cm}^{-2}$ - selectivity in a wide linear range $\left(0.1-120 \times 10^{-6} \mathrm{M}\right)$ with a detection limit of ca. $1 \mu \mathrm{M}$. Moreover, the method was successfully applied for hormone determination in the presence of interfering compounds (ascorbic acid, Lcysteine, uric acid).
\end{abstract}

Keywords: biosensor, EDCs, hormones, GQDs, laccase, semiconductive polymer, voltammetry techniques

\section{FULL TEXT}

(C) 2020 The Authors. Published by ESG (www.electrochemsci.org). This article is an open access article distributed under the terms and conditions of the Creative Commons Attribution license (http://creativecommons.org/licenses/by/4.0/). 